\title{
A New Era of International Economic Policy
}

\begin{abstract}
We distinguish between a "Friedman world" and a "Keynes world," the latter being characterized by the zero lower bound problem. With the natural rate of interest tending to fall over time, the Keynes world is becoming the norm. In the Keynes world, voters defend their interests as producers more than their interests as consumers. This strengthens protectionism at the ballot box. We are less and less able to rely on the USA to serve as the engine of the global economy via its high current account deficits. In addition to the WTO rules, an international fiscal order is needed to rescue free trade: 1 . At low real interest rates, countries with current account surpluses undertake to eliminate them by increasing government net borrowing. 2. At high real interest rates, countries with current account deficits undertake to eliminate them by cutting fiscal expenditure or raising taxes.
\end{abstract}

\subsection{Free Trade in Modernity}

The struggle between free trade and protectionism is at least as old as the modern period itself. In his The Wealth of Nations (1776), Adam Smith wrote against mercantilism, which provided the theory for the protectionist practice of the then hegemonic power France. It took seventy years for his plea for free trade to be translated into legislation in Britain. It was in no small measure this late (and temporary) triumph of the idea of free trade that led John Maynard Keynes to include the following phrase in the last paragraph of his General Theory: “... the ideas of economists and political philosophers, both when they are right and when they are wrong, are more powerful than is commonly understood. Indeed the world is ruled by little else. Practical men, who believe themselves to be quite exempt from any intellectual influences, are usually the slaves of some defunct economist. 
Madmen in authority, who hear voices in the air, are distilling their frenzy from some academic scribbler a few years back" (Keynes 1936, p. 383).

The classical school argued for free trade. Ricardo took up the thread from Adam Smith - and was even a member of the British House of Commons for a time. He developed his theory of comparative advantage as a justification for free trade. In Germany, Friedrich List wrote his National System of Political Economy (List 1841) as an argument against the free trade doctrine of the classical school. To use today's economic terminology, he pointed to the significant positive externalities of industrial activity, which would be denied a still backward country like Germany, if, in keeping with the classical doctrine, it had to compete with superior British industry on the basis of free trade. He thus argued for a German customs union with protective tariffs against British goods. We will come back to List's ideas in Chap. 12 on the developing countries and emerging economies.

In addition to purely economic considerations, freedom and international peace have always played an important role in the classical liberal arguments for free trade. Protectionist arguments, on the contrary, always also involve the idea that free trade is in reality a weapon of imperialism and colonialism. Hence, for centuries already, slogans like "prosperity through trade," "freedom through trade," and "peace through trade" have been facing off in public discourse against others like "(foreign) domination through trade," "colonization through trade," "free trade imperialism" and "exploitation through trade."

The free trade position predominates in modern economic theory. Among other reasons, this is due to the tremendous success that a regime of relatively free trade, under first the GATT rules and then the WTO rules, has had in fostering global prosperity-also precisely in many countries that were still very poor at the beginning of the postwar era in 1945 (cf. also Rosling et al. 2018). Nonetheless, economic theory has also, of course, contained indications that a simple, unnuanced free-tradism is inadequate. We can recall, in this connection, the Stolper-Samuelson Theorem (Stolper and Samuelson 1941) and the theory of international trade with imperfect competition (Krugman 1979).

The process of European unification got underway in the mid-1950s with the creation of a common market. On the model of domestic freedom of movement and domestic free trade in nation states, international, but still intra-European, free trade was used here as an instrument for establishing a peaceful European order. Even if emphasis was placed on the economic benefits of such a common market, the actual goal was the creation of an intra-European order that would end wars between the European nation states once and for all. The resiliency of European liberal democracy in the face of authoritarian or even totalitarian disturbances of external origin was also supposed to be heightened by the ongoing process of economically driven unification. We will come back to this point in the following chapter on the euro. 


\subsection{Free Trade or Import Barriers as Nash Equilibrium}

It is not our intention here to present a comprehensive political economy of international trade. We only want to call attention to the relationship between the overall macroeconomic situation and more or less strong tendencies toward "protectionism."

To start our analysis off, we again refer to John Maynard Keynes. To the astonishment of many of his contemporaries, in a newspaper article of April 7, 1931, Keynes called for British import tariffs. He argued that they were needed because of the high unemployment that had also developed in Great Britain since the October 1929 crash: job creation by eliminating foreign competition or at least making it more difficult (Krämer 2011). The proposal did not only contradict the prevailing opinion among economists, but also what Keynes himself had previously argued in the spirit of free trade. With his talent for pointed formulations, he wrote: "I seem to see the elder parrots sitting round and saying: 'You can rely on us'. Everyday for thirty years, regardless of the weather, we have said: 'what a lovely morning'. But this is a bad bird. He says one thing one day and something else the next" (Keynes 1931).

We know, of course, that tariff barriers are not an appropriate means for increasing total global employment in recessions or depressions. Nonetheless, a unilateral increase in import tariffs can have a positive effect on domestic employment in this sort of situation, as long as other countries do not respond with corresponding tariff increases ("beggar thy neighbor"). In game-theoretical terms, a free trade regime is not a Nash equilibrium under conditions of global underemployment, if import tariffs can be changed unilaterally.

The political prospects for free trade are far better when the global employment situation is good. It is possible that import tariffs or other import barriers will still find supporters. Nonetheless, it is generally known in this case that real national product cannot be increased by imposing import tariffs: The price increases resulting from such tariffs force the central bank to raise interest rates, which, in turn, drain demand from other sectors of the economy.

In a certain way (without wanting here to provide a precise mathematical formulation), we can say that in a world with low global unemployment, free trade is nearly a Nash equilibrium.

Of course, the real world is more complicated than this juxtaposition of global underemployment and global full employment suggests. The phenomenon of market asymmetry, which we already discussed in Chap. 9, is of particular significance. Market asymmetry is also the basis of neo-Keynesian macroeconomics. The theory of interest groups developed by Olson (1982) can help us to explain its political effects. According to Olson, it is easier for small groups to come together to defend their interests than it is for large groups. It is easier to achieve the "public good" of a common representation of interests, if the number of participating members in the group is small. Given specialization based on the division of labor on the supply side and diversification on the demand side, the number of sellers is 
considerably smaller than the number of buyers in almost every market for produced goods. The supply side also possesses the technical know-how required for manufacturing the goods. For these reasons, the supply side can defend its interests in the political arena better than the demand side.

This is why, by and large, import tariffs play a role in the political system and not export tariffs. Similarly, there are often export subsidies, which as "dumping" may distort competition, but only rarely import subsidies.

In parallel to the market asymmetry that we have just discussed, individual citizens also have "split personalities": They are normally both producers and consumers and thus both part of the economy's system of production and part of its system of consumption. The weighting of their preferences as producers or as consumers also depends to a very large degree on the overall economic situation. If unemployment is high, their interests as producers are the focus. At full employment, most people can count on finding work again if they lose their current job. Hence, the interest in favorable buying conditions, especially low prices, increases relative to the interest in keeping their current jobs. As a rule, the same people will be more protectionist, both in their thinking and in their political action, the worse the employment situation.

Negative experiences with resurgent protectionism as a result of the Great Depression moved the spiritual fathers of the post-WWII global economic order to propose and to implement a system of international trade that was supposed to stabilize free trade. This was the purpose of both the GATT and the IMF, as well as the Bretton Woods system of fixed exchange rates. The architecture of this system of trade was supposed to make unilateral protectionist measures, like tariffs and devaluations, unattractive. The aim was to prevent the formation of a Nash equilibrium seeped in protectionism. The fact that this liberation from protectionism largely succeeded was due not only to the cleverly constructed architecture of the system and an initially overvalued US dollar, but also to the market-inspired dynamics of the rebuilding of Western Europe and Japan, which led to high employment and a massive increase in prosperity.

The system of fixed exchange rates ultimately broke down: among other reasons, due to the crisis into which the Vietnam War precipitated the USA as hegemonic power. Nonetheless, the progress made in liberalizing global trade ensured that the GATT/WTO system survived. The re-emergence of a global capital market after two world wars and the cross-border direct investment associated with it contributed to economic life adjusting to the rules of globalization, thus giving rise to significant gains in prosperity.

In recent years, the symptoms of crisis in the globalized economic system have been multiplying. These symptoms are often connected to the policies of Donald Trump in public discussion. In our opinion, attributing the crisis to the eccentricities of a single individual is too superficial. We will try to provide a deeper explanation in the following sections. 


\section{3 "Friedman World" or "Keynes World"}

Every economist is familiar with the "liquidity trap." It is well known as an important building block of Keynes's General Theory. If the propensity to invest is low, even a nominal interest rate of zero may not be sufficient for private investment to absorb hypothetical private savings under conditions of full employment. The consequent "slump" is often exacerbated by the fact that price expectations are for deflation, so that potential investors may fear high real interest rates.

Locally or regionally deficient investment can then be offset at full employment, if there are other parts of the world where desired investment exceeds saving. In principle, the free movement of capital can thus serve to ensure that saving (S) matches investment (I) in the global economy even when employment is high. The interest rate level on the global capital market is then the pilot that brings the global "S" and the global "I" into line. If the interest rate can reach the "correct" level, a system of flexible exchange rates and free movement of capital is compatible with global prosperity at high global employment. We speak here of a "Friedman world" (Friedman 1953). Another feature of this world is that fiscal policy can be designed in a decentralized, i.e., autonomous, way and can vary from country to country. If one country has a restrictive public debt policy and if domestic saving is thus structurally greater than investment, this does not represent any danger to full employment, since the national surplus of savings can be invested on the international capital market to finance the excess investment of other countries. This then also corresponds to an excess of exports as compared to imports, which compensates for the domestic aggregate supply surplus. As a rule, however the price paid for this form of savings surplus is that domestic (real) interest rates are lower than the (real) rates in the recipient countries of the excess savings.

On the other hand, another country may run high deficits, so that domestic saving is not sufficient to finance domestic investment. The excess investment will then be made possible by capital imports, accompanied by a negative current account balance. Interest rates in this country are normally higher than in the countries of origin of the foreign savings.

But what happens if the level of the global full-employment real interest rate is so low that, due to the zero lower bound for the nominal rate, it can only be achieved through inflation? We assume that the goal of price stability should be maintained. In Chap. 9, we argued for this goal on the basis of the connection between monetary stability and the stability of the open society. If, with stable prices, the global full-employment real interest rate is so low as to be unattainable, then we are in a world that we will call a "Keynes world" (Keynes 1936).

In the Keynes world, international coordination of national macropolicies is required. Before going into the Keynes world in greater detail, we want to recall the well-known fact that there has always been a reference currency in times of free movement of capital. In the period before the First World War, the reference currency was the British pound. In the period since the Second World War, it is the 
US dollar. Special rules apply for the country that controls the reference currency. It is, in particular, far less vulnerable than other countries to balance of payment crises, since there is no threat of its own currency being devalued against the reference currency. For the two currencies are one and the same. Of course, the country of the reference currency must preserve at least a certain degree of monetary stability. For its currency to discharge the function of reference currency, it is also useful for foreign investment to enjoy a high degree of security in this country. The pound before the First World War and the US dollar since the Second World War have more or less fulfilled these conditions.

It was understanding that international coordination could be needed that led to the international meetings of heads of state and government that have been held for decades now and that are known to the public nowadays as the "G7" (or "G8") and the "G20." But, up to now, the dichotomy between "Friedman world" and "Keynes world" that we have presented here is not used in international economic diplomacy.

International coordination of macropolicies must also, of course, encompass international coordination of fiscal policy. In the Keynes world, the fiscal policies in question run in two opposite directions. On the one hand, in the Keynes world too, there are constantly countries that have accumulated too much debt and hence run the risk of insolvency. In the view of many stakeholders in the global financial system, such insolvencies have to be prevented, in order to preserve the stability of the system. The traditional role of the IMF includes providing support in such cases, but also actively intervening in and monitoring countries. But sometimes support packages have also been put together that go well beyond the lending resources of the IMF. The Greek debt crisis is an example. Since the impending insolvency often escalates into a crisis situation in a matter of just days or weeks, it becomes the focus of public attention. The government of a country that finds itself in such a crisis has to commit itself to consolidating public finances, i.e., to imposing "austerity."

By contrast, the opposite international need for coordination, namely that which goes in the direction of more expansionary fiscal policy, is a slow-burning candle under the conditions of the Keynes world. There is no doubt that international pressure has sometimes led countries to pursue a more expansionary fiscal policy than they would have done otherwise. The means used to exert this pressure, however, are basically incompatible with the principles of free trade. We will come back to this matter later in the chapter. But there is often no general consensus that, on average, a more expansionary fiscal policy course should be pursued globally.

How can we explain this lack of consensus? To start with, there is already no consensus on whether we are in a Keynes world or in a Friedman world. Those who are inclined to view the situation as a Friedman world will not have any understanding for more fiscal expansion. They will tend to view low interest rates on the capital market as a consequence of central bank policy. And they will tend to believe that the full-employment equilibrium interest rate corresponding to current fiscal policy is higher than the actually prevailing rate. Conversely, those who take the view that we are in a Keynes world will regard much of what is officially 
proclaimed as the expression of a misguided austerity policy, which is partly to blame for the fact that many countries are far from full employment.

In principle, it can never be ruled out that the world will be transformed in the near future from a Friedman world into a Keynes world - or, conversely, that it will be transformed from a Keynes world into a Friedman world. Whether such a transformation goes in the one direction or the other depends in no small measure on the evolution of countries' fiscal policies.

When the overall situation of the global economy is so opaque, it is difficult to get countries like Germany or the "northern" eurozone countries in general to abandon their current fiscal policy. The latter can always argue that there is a high probability that we are in a Friedman world. In "normal" times, moreover, the need for action is not so urgent, so that there is also no hurry to find a consensus.

The result is an asymmetry in international macroeconomic cooperation. If we are in a Keynes world, the excessive public debt of certain countries leads to crises, the overcoming of which involves massive restrictions on the debt of the countries in question. But an expansion of the debt of countries with "healthy" public finances, which would be useful from the point of view of monetary stability and higher employment, cannot be implemented due to a lack of consensus. In a Keynes world, the useful shifting of public debt from the less competitive countries to the more competitive countries thus fails to take place.

The more competitive countries tend to see the world as a Friedman world.

The less competitive countries tend to see the world as a Keynes world.

\subsection{The Natural Rate of Interest, the Friedman World and the Keynes World}

We can define a transitional zone for the risk-free real interest rate on the capital market. This zone consists of the range of real, risk-free interest rate levels at which a transition from the Friedman world to the Keynes world or a transition from the Keynes world to the Friedman world is to be regarded as a real possibility, such that people's thinking and actions adapt to the imminent danger or opportunity that such a transition represents. In this transitional zone, there will normally also be disagreement about whether we are currently in a Friedman world or a Keynes world.

Figure 10.1 provides a graphic representation of this idea. The red line represents the relationship between the global level of public debt $D$ (plotted on the horizontal axis) and the equilibrium interest rate at (hypothetical) full employment. The latter is plotted on the vertical axis. As discussed in Chap. 2 on capital-theoretical foundations, we understand $D$ as the independent variable and $r$ as the dependent variable here. The natural rate $\rho$ ("rho" in the graph) is located 


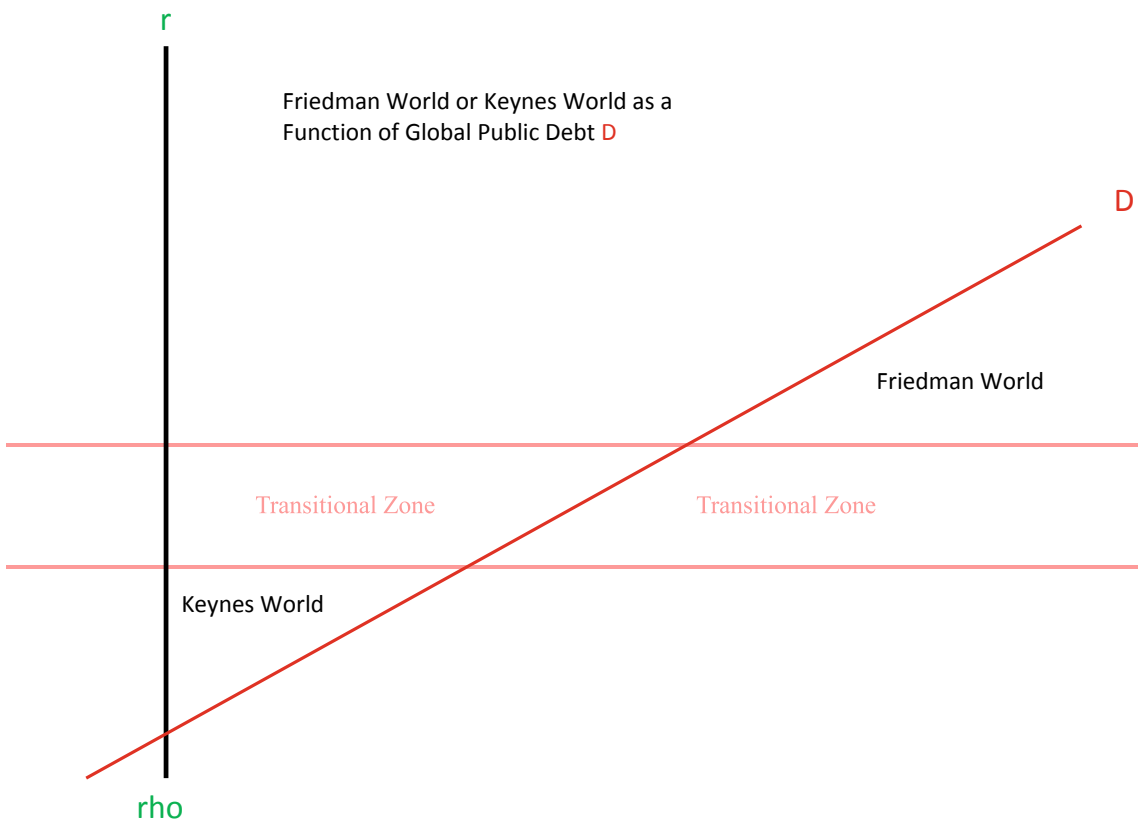

Fig. 10.1 Friedman world or Keynes world as a function of global public debt. Source Authors' own presentation

where $D=0$. At a high level of global public debt $D$, there is no doubt that we are in a Friedman world. At a very low level of public debt $D$, there is no doubt that we are in a Keynes world, since, due to the liquidity trap, central banks cannot lower the interest rate to the level required for full employment under conditions of price stability. As we have drawn the graph, $\rho$ is in the range of the Keynes world: Full employment with stable prices is only possible, if global public debt is positive. Further up, there is the transitional zone, in which the transition from a Keynes world to a Friedman world or, vice-versa, from a Friedman world to a Keynes world is not unlikely. In this transitional zone, there is also no consensus about whether we are currently in a Friedman world or in a Keynes world.

Now, it is obvious that the position of the natural rate $\rho$ is of great significance for the international coordination of economic and, especially, fiscal policy: The natural rate of interest is the point of intersection between the red $D-r$ curve and the vertical axis on which the full-employment rate is plotted. At a constant slope of the $D-r$ curve, the lower the natural rate is, the larger is the range of the Keynes world and the smaller is the range of the Friedman world. If, as we have argued in this book, there is a secular tendency for the natural rate of interest to fall, then there is also a secular tendency for the range of the Keynes world to grow and the range of the Friedman world to shrink. The need for international coordination of fiscal policy is thus growing. 


\subsection{Unilateral Action and the Rules of Free Trade}

It has always been the case that the rules of free trade are not respected in their pure form. Tariff and non-tariff import barriers and conscious intervention in foreign exchange markets are of particular relevance here. Within the framework first of the GATT and then of the WTO, there were and are procedures whose purpose is to keep tariff and non-tariff barriers to trade in check and, if possible, to reduce them. We do not want to go into the details here. We should, however, recall the following point on which experts are agreed: The stronger the global economy, the easier it is to contain and to dismantle barriers to trade.

A second field of unilateral action is targeted intervention in currency markets by central banks, in order to alter the competitiveness of their country's economy. As a rule, a country intervening to devalue its currency provokes greater consternation among other countries than intervention in the opposite direction. In the short and medium terms, devaluing the currency increases a country's competitiveness, but, at the same time, it increases inflationary pressures on the domestic market and undermines international trust in the currency in question.

As shown above, the following can be observed: If real interest rates are high internationally, then this is a price signal for capital scarcity. If the employment situation is good, then net capital imports are welcome from a country's perspective - and hence so too are the current account deficits that go with them. If real interest rates are low internationally, then a full-employment equilibrium is precarious. The danger of slipping into a recession or even a depression then shapes the general perception of the situation and the discussion in the media. In this case, the global economy is either in a Keynes world or not far from it.

We can again use the image of the "split personality" in comparing high and low full-employment real interest rates. If citizens are always both (potential or actual) producers and consumers, the focus is on their role of consumers when there is full employment with high real interest rates, since the risk of long-term unemployment is low. If full employment is not assured and the real rate is low, then citizens are interested, above all, in their role as producers. In this case, their thinking and action is determined especially by job concerns.

In light of the finding of the previous section, we can draw the following conclusion:

When the natural rate of interest falls, the weight of the producer in the voter's split personality rises at the expense of the weight of the consumer. The political economic situation is thus a function of the level of the natural rate of interest.

The WTO is an institution that has only limited possibilities for imposing sanctions on member states that violate its rules. Among other things, WTO proceedings are long and drawn-out. As we could see in the recent past, moreover, a 
member state like the USA can effectively paralyze the WTO dispute settlement apparatus. Hence, the rules of free trade can only be upheld, if the most important WTO members really want to uphold them.

But the ability to act of the governments of WTO member countries depends on there not being massive opposition among the majority of voters. Otherwise, sooner or later, the moment comes when the member in question resorts to unilateral measures that are not in accordance with the rules of free trade, but that-rightly or wrongly - are regarded as beneficial to voters' job security.

\subsection{The New Protectionism}

The election of Donald Trump and the trade policy that he has pursued as president are symptomatic of the fact that forces in the global economy have shifted in the direction of protectionism. Trump's election-which hardly anyone expected a year earlier-was not, in our view, an inexplicable "accident." It points to a change in the electorate, which is less and less impressed by the achievements of globalization and is assigning more and more weight to its costs in the form of job losses.

Modern protectionism can thus be understood as a contemporary version of anti-machinery "Luddite" movements. The fear of losing one's job that is provoked by advances in digitalization are a modern form of the fears that the invention of the spinning machine and the mechanical loom provoked in their time. Trump's 2016 election as president of the USA is thus a symptom of a natural rate of interest that is becoming increasingly negative.

There is no doubt that the USA is one of the main "winners" in the process of globalization. We have only to think of the sensational global changes coming from Silicon Valley and other American hubs of digital innovation. If there were no grateful global market for the products of the American IT industry, its profits would be far lower. The model of producing software in the USA, but the hardware in China led to the earlier incredible success of these companies on the stock exchange. As of the end of December 2020, the five most valuable companies in the world are currently American digital pioneers.

Globalized finance has also contributed to increased prosperity in the USA. The global investment market does not only create substantial income streams for financial professionals in its capital New York, but also for their American customers. Many middle-class Americans derive a considerable part of the income on their savings from the dividends of American and non-American multinational companies. A large part of the shares of the major Germany companies included in the DAX-30 index are held by American funds. The influx of foreign capital into the USA also promotes American prosperity. The return on these investments is far lower than the return on American capital invested abroad as shareholdings. By far the greater part of the foreign capital in the USA is invested in fixed-rate assets: to a large extent, in American treasury bonds. This means that American investors can borrow at far lower interest rates than they could without these capital imports. 
This phenomenon has, after all, been described by Bernanke as a "saving glut" (Bernanke 2005).

Nevertheless, the discussion among American voters is increasingly focused on the relocation of jobs abroad within the framework of globalized value chains. (There is a growing literature on this subject. Cf., for example, Rodrick 2018 and Komlos and Schubert 2019, which includes extensive bibliographical references.)

Trump used his executive powers to impose a protectionist line. This included employing measures that are usually not regarded as part of trade policy at all: like, for example, the sanctions against Iran. As is well known, the latter also affect German firms, which Trump has threatened to exclude from the American market unless they stop their deliveries to Iran. The protectionist line of American trade policy is now also part of President Biden's agenda. If he wants to maintain and increase voters' support in the mid-term elections, he needs to be protectionistunless, as we propose below, free trade rules are complemented by obligations of WTO members to aim at nearly zero disparity between exports and imports.

Recent US trade policy highlights a strength that the USA has always had. The USA represents the largest domestic market in the world. For many exporters, especially from Asia, it is an even more important sales market than the European Common Market. If we take, for example, the current conflict between the USA and China, the USA holds the better cards, because American imports from China are far greater than Chinese imports from the USA. (Cf. also Felbermayr 2019, as well as Fetzer and Schwarz 2019. The latter analyze the political economy of the new trade policy using simulations.)

In times in which the full-employment level of the interest rate is either in the range of the Keynes world or in the transitional zone, access to the domestic market is the strongest card that a country or a common market comprising several countries can play in trade diplomacy. This is the strength that Trump was exploiting in his international trade policy (cf. also Simon 2019). Politically, Biden cannot afford not to play this card. He may do this with greater diplomatic skill than his predecessor, but he will remain protectionist.

This strength is further increased by the USA's high current account deficit. If tariff barriers are set up everywhere, the job losses appear to be greater for voters in the USA's supplier countries than for voters in the USA itself. In other words: One can suggest to American voters that high tariff barriers that are the same level for American imports and exports amount to a "re-importing" of American jobs. (The trained specialist in macroeconomics knows that things are more complicated in the context of a general equilibrium and cannot be reduced to such a "re-import" optic.)

In an interview with the Financial Times (July 20, 2018), Henry Kissinger let it be known that: "I think Trump may be one of those figures in history who appears from time to time to mark the end of an era and to force it to give up its old pretenses" (Kissinger 2018). Kissinger may be right. In matters of trade policy, Trump may have been not so much the cause of the new protectionism as its beneficiary. American trade negotiators can be expected to continue playing the card of the USA's strength even after the end of the Trump era-under pressure from an electorate for whom jobs have become more important than low prices. 
Even before Trump, the USA occasionally exerted political pressure to make exports to the USA more difficult. In East Asia, Japan depends on the US military for protection. With the growing military power of China, this dependency is becoming greater. Moreover, Japan has long relied on being able to export to the USA without major trade barriers. Thus, decades ago already, the USA "forbade" Japanese authorities from devaluing the yen, so that private Japanese savings, which exceed full-employment investment, could be diverted abroad. As consequence, Japan had to offset these excess private savings by high fiscal deficits, in order to maintain full employment with only a slight export surplus. We presume that the Japanese population would have preferred a different economic policy solution.

\subsection{A Multilateral Balanced Account Agreement}

From our finding that the natural interest rate level is already negative today and will tend to slide even further into the minuses in the future, we conclude that there will likely be no going back to the de facto rules of the pre-Trump era. If free trade is preserved and if most other currencies remain convertible into US dollars, the interest rate in dollars will no longer rise to levels corresponding to an undeniable return to the Friedman world. Under these conditions, the net inflow of large amounts of capital into the USA will ensure that real interest rates in dollars remain low. In political-economic terms, however, such a hypothetical situation is not sustainable. Due to high current account deficits, American voters will compel any congressional majority to play the card of the USA's large domestic market, just as has happened vis-à-vis Japan for decades already and as Trump has done in generalizing the earlier Japan policy.

Our proposal for modifying the international trade regime is intended to safeguard free trade in political-economic terms. We thus propose:

\section{A multilateral balanced account agreement}

The OECD plus China region undertakes to uphold the rules of free trade. At the same time, however, each currency area in this region undertakes to bring its current account balance close to zero by using appropriate fiscal measures.

We will say something about the implementation below. For the moment, let us just note the following: If the current accounts of the currency areas are more or less balanced, then it will always be possible to respond to the advocates of protectionist measures that foreign retaliatory measures will cost about as many jobs as the original measures "gain." Protectionists in countries with current account deficits are thus deprived of a popular argument. 
As we have shown, the resurgence of protectionism is tied to low real interest rates, which can be attributed, in turn, to the already negative and still falling natural rate. If, however, real interest rates are below the steady state growth rate of a country, then additional public debt does not represent any additional burden on future generations. If, furthermore, the additional debt is used to promote public and private investment, then it even increases prosperity as compared to investing the excess savings abroad at low interest rates. At low interest rates, the additional public debt for the purpose of eliminating a current account surplus is thus a better way of providing for the future, even when we leave aside the free trade that it "purchases" (cf. also Blanchard 2019).

Although risk-free real interest rates will remain low in our opinion, the proposed balanced account agreement should also be enacted if the level of the real rate is high at full employment. In this case, the countries with current account surpluses should not be required to increase their public debt. It is up rather to the countries with current account deficits to diminish the latter by slowing down the growth in their public debt.

A kind of symmetry thus comes into being. The agreement has the effect of shifting the interest rate in the direction of the economy's growth rate. At an interest rate level below the growth rate, the countries with current account surpluses increase their public debt, as a consequence of which global interest rates rise. At an interest rate level above the growth rate, the countries with current account deficits reduce their public debt, as a consequence of which global interest rates fall. These corrections based on the balanced account agreement increase overall prosperity in the OECD plus China region, because the Golden Rule of Accumulation applies (cf. Chap. 2 on capital-theoretical foundations). But they also increase prosperity in the countries that are required to undertake the corrective measures: For even apart from the balanced account agreement, when interest rates are low, it makes sense for a country to increase its public debt, in order to finance more public investment and/or reduce taxes that have distorting allocational effects. And even apart from the balanced account agreement, when interest rates are high, it makes sense for a country to roll back public debt, in order not to have a heavy debt service burden in the future.

\section{References}

Bernanke, Ben. 2005. The global saving glut and the U.S. current account deficit. Speech 77. Washington (D.C.): Board of Governors of the Federal Reserve System.

Blanchard, Olivier. 2019. Public Debt and Low Interest Rates, AEA Presidential Lecture 2019. American Economic Review 109 (4): 1197-1229.

Felbermayr, Gabriel. 2019. „Es geht um die Weltherrschaft” (Interview). Handelsblatt. 6 May 2019.

Fetzer Thiemo and Carlo Schwarz. 2019. Tariffs and Politics: Evidence From Trump's Trade Wars. CES-Ifo Working Paper 7553. Munich: Ifo-Institut.

Friedman, Milton. 1953. The Case for Flexible Exchange Rates, in: Essays in Positive Economics, ed. Milton Friedman, 157-203. Chicago (IL): University of Chicago Press. 
Keynes, John Maynard. 1931. Economic Notes on Free Trade II. New Statesman and Nation. 7 April 1931.

Keynes, John Maynard. 1936. The General Theory of Employment, Interest and Money. London: Macmillan.

Kissinger, Henry. 2018. Henry Kissinger: "We are in a very, very grave period" (Interview). Financial Times. 20 July 2018.

Komlos, John and Hermann Schubert. 2019. Die Entwicklung sozialer Ungleichheit und ihre politischen Implikationen in den USA. Wirtschaftsdienst 99 (3): 216-223.

Krämer, Hagen M. 2011. Keynes, Globalisierung und Strukturwandel. In Keynes 2.0 - Perspektiven einer modernen keynesianischen Wirtschaftstheorie und Wirtschaftspolitik. Jahrbuch Ökonomie und Gesellschaft 23, eds. Harald Hagemann and Hagen Krämer, 183-215. Marburg: Metropolis-Verlag.

Krugman, Paul. 1979. Increasing Returns to Scale, Monopolistic Competition, and International Trade. Journal of International Economics 9: 469-479.

List, Friedrich. 1841. Das nationale System der politischen Ökonomie. Stuttgart: Cotta.

Olson, Mancur. 1982. The Rise and Decline of Nations: Economic Growth, Stagflation and Social Rigidities. New Haven (CT): Yale University Press.

Rodrick, Dani. 2018. Populism and the economics of globalization. Journal of International Business Policy 1(1-2): 12-33.

Rosling, Hans, Ola Rosling and Anna Rosling Rönnlund. 2018. Factfulness. New York (NY): Flatiron Books.

Simon, Hermann. 2019. Die Macht der Mächte. Frankfurter Allgemeine Zeitung, 6 June 2019.

Smith, Adam. 1776. An Inquiry into the Nature and Causes of the Wealth of Nations. London: W. Strahan and T. Cadell.

Stolper, Wolfgang and Paul A. Samuelson. 1941. Protection and Real Wages. Review of Economic Studies 9 (1): 58-73.

Open Access This chapter is licensed under the terms of the Creative Commons Attribution 4.0 International License (http://creativecommons.org/licenses/by/4.0/), which permits use, sharing, adaptation, distribution and reproduction in any medium or format, as long as you give appropriate credit to the original author(s) and the source, provide a link to the Creative Commons license and indicate if changes were made.

The images or other third party material in this chapter are included in the chapter's Creative Commons license, unless indicated otherwise in a credit line to the material. If material is not included in the chapter's Creative Commons license and your intended use is not permitted by statutory regulation or exceeds the permitted use, you will need to obtain permission directly from the copyright holder. 